\title{
Pushover Analysis of Partially Strengthened Column Structures on an Existing Multi-story Building
}

\author{
Mochamad Teguh ${ }^{1, *}$, Novia Mahlisani ${ }^{2}$, and Fadillawaty Saleh $^{3}$ \\ ${ }^{1}$ Department of Civil Engineering, Universitas Islam Indonesia, Indonesia \\ ${ }^{2}$ Alumni of Master Program in Civil Engineering, Universitas Islam Indonesia, Indonesia \\ ${ }^{3}$ Department of Civil Engineering, Muhammadiyah University of Yogyakarta, Indonesia
}

\begin{abstract}
A pushover analysis was conducted to evaluate structural performance of an extended building structure subjected to simulated seismic loads. The Inna Garuda Hotel was selected as a building object of this research focusing on the extension building only. This 7-story reinforced concrete building has been functioned as a hotel building in the Yogyakarta City of Indonesia for over 30 years. Preliminary results of this analysis indicated that the performance level of this building was categorized as an immediate occupancy (IO), however, the plastic hinges on the slim column structure components occurred. Given this condition, the structure of the building does not fulfill the concept of a strong columnweak beam (SCWB). The research objective is to follow up on the potential of building collapse due to the column structure weakness by conducting a research on the strengthening of slim column elements. A pushover analysis was carried out using ETABS software. A strengthening technique was adopted by enlarging the dimensions of the slim column gradually. In this study, the slim column was enlarged up to $300 / 650 \mathrm{~mm}$ (KJ-P5 model). The pushover analysis results of the KJ-P5 model have shown the drift ratio is less than $1.0 \%$ for the four directions of the pushover with the level of immediate occupancy performance (IO). Referring to the recent building condition, the strengthened slim columns do not seem significant damage to the structural components of the building resulting in a fulfilling of SCWB concept, where a similar condition on their strength and stiffness as before the earthquake occurs. The results of the plastic hinge locations, as well as the performance levels of the indicated slim columns in resisting overall structures, are extensively discussed in this paper.
\end{abstract}

Keywords: pushover analysis, slim and strengthened column, existing building

\section{Background}

In a recent seismic design of reinforced concrete (RC) building structures, special moment frames are commonly used as seismic resisting systems to withstand earthquake forces by

*Corresponding author: m.teguh@uii.ac.id 
considering a strong column-weak beam (SCWB) concept [1]. In this concept, all moment frame elements (beams, column, and beam-column hinges) should be proportioned and well detailed in order to sufficiently resist flexural, axial, and shearing forces. During strong earthquake ground motion, the building structure sways through multiple displacement cycles due to seismic actions. Given this condition, a reinforced concrete frame should be designed with special proportioning and detailing requirements to resist strong earthquake shaking without its strength reduced.

Yogyakarta is a vulnerable area to earthquakes due to tectonic plate collision, local fault-on-land, and volcanic activities. Yogyakarta is tectonically a region with a high level of seismic activity in Indonesia due to its location is adjacent to plate collision zone. Besides very vulnerable to earthquakes due to tectonic plate collision activity, Yogyakarta is also very prone to earthquakes due to local fault-on-land activities. The consequences of the earthquake caused the loss of life caused by the ruins of the building. From the field review, it was seemed that most of the non-engineered and engineered buildings were heavily damaged and collapsed because these buildings had high levels of vulnerability. Buildings classified as engineered buildings are buildings of public facilities, while nonengineered buildings are community or residential houses [2].

One of the public facilities affected by the 2006 earthquake was an existing hotel. From Java Media-Tourism Crisis Center (JM-TCC) data, a number of nonstar-rated and/or starrated hotels in Yogyakarta suffered from minor damage to heavy damage. The FEMA 302 [3] standard states that the hotel buildings belong to the second utility group, which is a public facility building with a large number of people who work in it quite a lot. This building categorized as the group II should have a performance level of immediate occupancy (OI) that is when it is hit by an earthquake must remain in operation, although not in full, damage to lightweight structures, so it is safe to be inhabited. One of the public facilities affected by the 2006 earthquake was an existing hotel. From Java Media-Tourism Crisis Center (JM-TCC) data, a number of non-star-rated and/or star-rated hotels in Yogyakarta suffered from minor damage to heavy damage. The FEMA 302 [3] standard states that the hotel buildings belong to the second utility group, which is a public facility building with a large number of people who work in it quite a lot. This building categorized as the group II should have a performance level of immediate occupancy (OI) that is when it is hit by an earthquake must remain in operation, although not in full, damage to lightweight structures, so it is safe to be inhabited.

Inna Garuda hotel was one of the hotels affected by the 2006 Yogyakarta Earthquake and suffered minor damage. This building is the oldest hotel was built in 1908 and located in the Malioboro tourist area. This hotel has been renovated several times. In 1983 Inna Garuda hotel was first renovated with a number of floor 7 floors considering the old version of Indonesian Standard. An extension building with 7 floors and the total height of $26 \mathrm{~m}$ was built in 1989. Patria [4] conducted a structural evaluation of the extended Inna Garuda Building based on SNI 1726-2012 [6]. This hotel extension is categorized as an irregular building forming an " $L$ " type of midrise (4-7 floors) which is prone to structural damage caused by earthquake forces. Based on a current pushover analysis carried out with ETAB's program, there are many plastic hinges in the column element components, especially at the ground floor, therefore the potential damage could be predicted to occur in some elements of the column. Having such plastic hinges condition, the existing building of Inna Garuda hotel extension did not meet the SCWB criteria. To overcome the problem, an advanced research on the strengthening slim column elements was conducted to recheck the structural performance of the building by carrying out a pushover analysis and magnification of dimensions on the slim column was simulated gradually to define maximum dimension up to $300 / 650 \mathrm{~mm}$ (KJ-P5 model). Based on the recent analysis results, the effectiveness of strengthening technique on the indicated weakness columns could be checked whether the 
building structure had met with the specified performance level and prediction of the damage location [5].

\section{Theoretical Basis}

\subsection{Nonlinear analysis}

Buildings located in an earthquake-prone area, their structures should be well designed to protect buildings against seismic action however no structure may be entirely immune due to damage from earthquakes. Therefore the implementation of earthquake-resistant construction is unavoidable to erect structures that fare better during seismic activity than their conventional counterparts. In general, the principles of earthquake-resistant building design philosophy are described as follows ([7], [8]).

1. In small earthquakes (light, or minor earthquake) that often occur, then the main structure of the building should not be damaged and be functioning properly. Minor defects that can still be tolerated on non-structural elements are still allowed.

2. In moderate earthquakes are relatively rare, then the main structure of the building may be lightly damaged/cracked but can still be repaired. Non-structural elements may be damaged but can still be replaced with new ones.

3. In a rare earthquake (strong earthquake), the building may be damaged but not totally collapsed. Such a condition is also expected in large earthquakes, whose goal is to maximize in protecting building occupants to the maximum.

Before implementing the earthquake-resistant building design, it is essential to design building structures in the right manner by conducting an analysis of the structure completely. Static pushover analysis according to SNI 1726-2012 [6] is a two dimensional or linear, nonlinear, or 2-dimensional static analysis method with the effect of earthquake plan on building structure is considered as static loads that capture at the center of each mass, and each floor. In the static nonlinear analysis, the mathematical model of the structure utilizes loads that have nonlinear characteristics of each component and building element. The nonlinearity adopted in the pushover analysis includes nonlinearity of the material, where if a material is stretched beyond the proportional limit, the relationship between stress and strain is no longer linear, for example in the plastic hinge of the beam [9].

Table 1. Limitation of drift ratio for performance level [7]

\begin{tabular}{|l|c|c|c|c|}
\hline \multirow{2}{*}{ Drift limitation } & \multicolumn{4}{|c|}{ Level of structural performance } \\
\cline { 2 - 5 } & $\begin{array}{c}\text { Immediate } \\
\text { Occupancy }\end{array}$ & $\begin{array}{c}\text { Damage } \\
\text { Control }\end{array}$ & Life Safety & $\begin{array}{c}\text { Structural } \\
\text { Stability }\end{array}$ \\
\hline Maximum total drift & 0.01 & $0.01-0.02$ & 0.02 & $0.33 \cdot \frac{V_{i}}{P_{\bar{i}}}$ \\
\hline $\begin{array}{l}\text { Maximum inelastic } \\
\text { drift }\end{array}$ & 0.005 & $0.005-0.015$ & Not limited & Not limited \\
\hline
\end{tabular}

Note: $V_{i}$ and $P_{i}$ are the total shear force and the total gravity on floors $i^{\text {th }}$, respectively.

There are several ways to examine the displacement target to determine the performance points of the building with a pushover analysis, one of which is the ATC-40 [7]. The capacity spectrum method presents graphically two graphs spectrum, the capacity spectrum that describes the capacity of the structure as a base shear with the lateral displacement of 
the structure (usually set at the top of the building) and the spectrum demand that describes the amount of demand (performance demands) due to the earthquake with a certain repeat period [10]. Consequently, the two most important aspects of performance-based design are demand and capacity representing an earthquake load and the ability of the structure to withstand earthquake loads, respectively. The intersection of the capacity curve and the demand curve produces a performance point of the structure. ATC-40 [7] provides deformation limitations for different levels of building structure performance, such as immediate occupancy (IO), damage control (DC), life safety (LS), and structural stability (SS) as denoted in Table 1. The maximum total displacement is defined as the story-drift on the displacement of performance points, whilst the maximum inelastic is formulated as part of the maximum total displacement below the yield point.

\subsection{Strengthening technique}

Repair and/or retrofitting of structures or structural elements is required in case of material degradation resulting in non-fulfillment of technical requirements, such as strength, stiffness, stability, and durability. The non-fulfillment of these requirements is not only caused by damage but also changes in compliance (code) with more stringent requirements, it may be that the structure previously considered to be eligible, but no longer exists, so reinforcement action is required [11]. There are two types of improvements that can be undertaken in retrofitting work namely repairing and/or strengthening. The term of repairing applies to buildings that have been damaged, which has been a decline in strength, to be restored as before. While the strengthening is an act of structural modification, there may not have been any damage, with the aim to resist the loads greater due to changes in building function and stability.

The strengthening is conducted to increase the strength capacity, stiffness or ductility of the structure, described as follows.

1. The strength, the expected reinforcement can increase the strength of the existing structure, i.e. at the level where the structure or component will begin to fail.

2. The stiffness, most strengthening methods also affect the stiffness of the structure, i.e. its ability to deform (shake) when an earthquake force occurs. Rigid structures deform lesser than flexible structures when exposed to the same seismic force.

3. The strengthening method is strongly desired to increase the ductility of the existing structure, i.e. the ability to deform repeatedly before failure.

In general, the retrofitting is caused by several things, among others: poor design, poor construction, changes in the function of buildings that result with the addition of the load, the occurrence of structural damage, the emergence of complaints against the comfort of the structure, increase the security value of a building (safety requirement), and changes in requirements to comply with new regulations (building code requirement). Various methods are commonly used in retrofitting for a reinforced concrete construction such as the shear wall, CFRP, and concrete jacketing techniques. Murty et al. [12] summarize them in the table of retrofit methods and their impact on structural characteristics as presented in Table 2.

Table 2. Strengthening methods and their impact on structural characteristics [12]

\begin{tabular}{|l|c|c|c|}
\hline \multirow{2}{*}{ Strengthening method } & \multicolumn{3}{|c|}{ Enhancement } \\
\cline { 2 - 4 } & Strength & Stiffness & Ductility \\
\hline Shear wall installment & Yes & Affected & Affected \\
\hline CFRP & Yes & Affected & Affected \\
\hline Concrete jacketing & Yes & Medium & Medium \\
\hline
\end{tabular}


Coating or commonly referred to as jacketing, a shell material that can protect concrete against damage. This sheathing material may be steel, rubber, concrete or composite metal. One of the most commonly used jacketing methods is concrete jacketing. The concrete jacketing is a retrofitting technique by coating all or part of the surface of structural elements with new concrete reinforced by longitudinal reinforcement and stirrup. The newly added reinforced concrete must have a higher or at least equal to the original compressive strength of concrete and the tensile strength of reinforcing steel as well in order to maximize the addition of structural strength capability [13].

\section{Analysis of results and discussion}

The calculation steps begin with simulating the enlargement of the slim column dimensions that are conducted gradually. The simulation for achieving an expected dimension was performed five times of pushover analysis under the same seismic load, and the fifth simulation was the best slim column dimension used in this research to recheck the existing building performance. The slim columns layout of the extension building structure shown in Fig. 1 consists of 4 levels having typical plans. Fig. 1 also presents the indicated damage points on the slim columns as circled with red marks. Table 3 shows the simulation sequence of slender column dimensions starting from the initial dimensions of $150 / 500 \mathrm{~mm}$ to $300 / 650$ $\mathrm{mm}$.

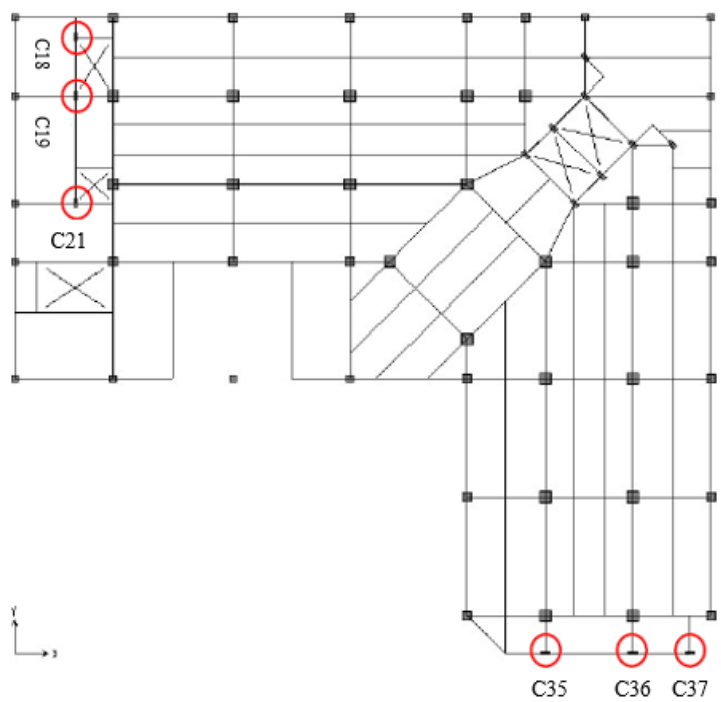

Fig. 1 Indicate damage points on slim columns

Table 3. Dimensional enlargement on slim columns

\begin{tabular}{|c|c|c|c|}
\hline \multirow{2}{*}{$\begin{array}{c}\text { Type of existing } \\
\text { column }\end{array}$} & $\begin{array}{c}\text { Initial dimension } \\
(\mathbf{m m})\end{array}$ & \multicolumn{2}{|c|}{ Strengthened column (RC jacketing) } \\
\cline { 3 - 4 } & & $\mathbf{T y p e}$ & New dimension $(\mathbf{m m})$ \\
\hline \multirow{4}{*}{ KJ } & \multirow{3}{*}{$150 / 500$} & $\mathrm{KJ}-\mathrm{P} 1$ & $200 / 500$ \\
\cline { 3 - 4 } & & $\mathrm{KJ}-\mathrm{P} 2$ & $250 / 500$ \\
\cline { 3 - 4 } & & $\mathrm{KJ}-\mathrm{P} 3$ & $300 / 500$ \\
\cline { 3 - 4 } & & $\mathrm{KJ}-\mathrm{P} 4$ & $250 / 600$ \\
\cline { 3 - 4 } & & $\mathrm{KJ}-\mathrm{P} 5$ & $300 / 650$ \\
\hline
\end{tabular}




\subsection{Nonlinear static analysis (Pushover)}

From the spectral response curve of the plan in accordance with SNI 1726-2012 [6] for buildings at the city of Yogyakarta and the soil conditions, was obtained values of $S_{d s}=$ 0.77 and $S_{d l}=0.46$ and they were required as input data in ETAB's program. Based on the result of ATC-40 [7] capacity spectrum analysis, the data for determining the performance level in each direction of the building structure for the KJ-P5 model could be found as listed in Table 4.

Table 4. Performance point of KJ-P5 model using the ATC-40 method [7]

\begin{tabular}{|c|c|c|c|c|c|c|c|c|}
\hline \multirow{2}{*}{$\begin{array}{c}\text { Lateral load } \\
\text { direction }\end{array}$} & \multirow{2}{*}{$\begin{array}{c}\text { Base } \\
\text { shear }\left(V_{y}\right) \\
(\mathrm{kN})\end{array}$} & \multicolumn{7}{|c|}{ Performance Point } \\
\cline { 5 - 10 } & & $V_{t}(\mathrm{kN})$ & $\delta_{t}(\mathrm{~m})$ & $S_{a}$ & $S_{d}$ & $T_{\text {eff }}$ & $\beta_{\text {eff }}$ \\
\hline \multirow{2}{*}{$\mathrm{X}$} & North-South & 9310.08 & 11170.296 & 0.125 & 0.143 & 0.106 & 1.728 & 0.178 \\
\cline { 2 - 9 } & South-North & 10299.90 & 11078.263 & 0.125 & 0.142 & 0.106 & 1.731 & 0.178 \\
\hline \multirow{2}{*}{$\mathrm{Y}$} & West-East & 12396.50 & 12681.988 & 0.131 & 0.153 & 0.092 & 1.551 & 0.128 \\
\cline { 2 - 9 } & East-West & 12116.30 & 12789.021 & 0.145 & 0.152 & 0.103 & 1.647 & 0.168 \\
\hline
\end{tabular}

\subsubsection{Lateral load in the $x$-direction}

It should be noted that the total height of the building is $26 \mathrm{~m}$ and the limitation of drift ratio for performance level refers to ATC-40 [7] as shown in Table 1. Based the performance point results of the KJ-P5 model (Table 4), the maximum drift and inelastic drift maximum due to lateral loads either in the pushover on the north to the south direction or vice versa can be calculated as follows.

a. Pushover on the north to south directions

Maximum drift due to lateral load $=0.125 / 26=0,004808<0.01$.

Building performance level of the building structure is immediate occupancy (IO). Inelastic drift maximum due to lateral load $=(0.125-0.026) / 26=0.003808$.

b. Pushover on the south to north directions

Maximum drift due to lateral load $=0.125 / 26=0.004808<0.01$.

Building performance level of the building structure is immediate occupancy (IO). Inelastic drift maximum due to lateral load $=(0.125-0.026) / 26=0.003808$.

\subsubsection{Lateral load in the $y$-direction}

a. Pushover on the west to east directions

Maximum drift due to lateral load $=0.131 / 26=0.005038<0.01$.

Building performance level of the building structure is immediate occupancy (IO). Inelastic drift maximum due to lateral load $=(0.131-0.026) / 26=0.004038$.

b. Pushover on the east to west directions

Maximum drift due to lateral load $=0.145 / 26=0.005577<0.01$.

Building performance level of the building structure is immediate occupancy (IO). Inelastic drift maximum due to lateral load $=(0.145-0.026) / 26=0.004577$. 


\subsection{Plastic hinge and prediction of damage location}

The location elements experiencing plastic hinge conditions at certain levels according to the performance level. Based of damage to structural elements is presented based on the results of pushover analysis by looking at structural on the graph of ATC-40 [7] referring to Fig. 2, the relationship between load-deformation and boundary level criteria in accepting deformation with the description of damage level is described.

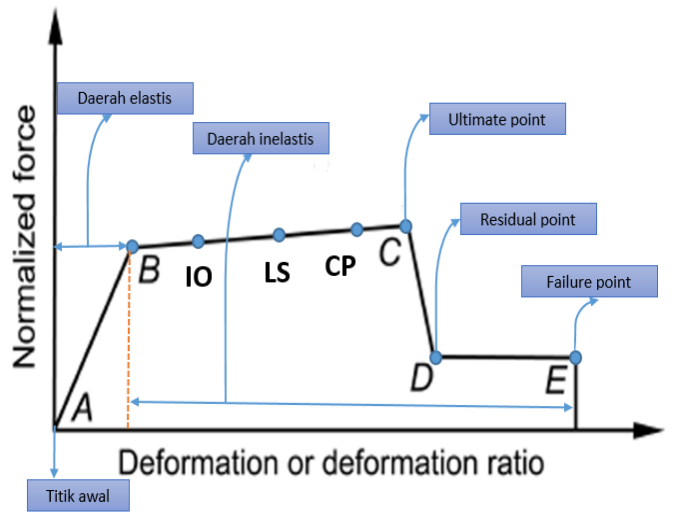

Fig. 2. Load-displacement relationship and damage level [7]

In the pushover analysis of this building, the degradation of building strength is marked by changes in the color of spherical points during the analysis process and it is presented from the animation of the structure with the color changes from purple to red. Table 5 presents a description of structural strength degradation during the analysis process.

Table 5. Color levels in plastic hinges degradation

\begin{tabular}{|c|c|l|}
\hline Color level & Symbol & \multicolumn{1}{|c|}{ Description of structural strength degradation } \\
\hline B & $\bigcirc$ & $\begin{array}{l}\text { Showing the linear limit which is then followed by the first } \\
\text { yielding of the structure }\end{array}$ \\
\hline IO & $\bigcirc$ & $\begin{array}{l}\text { Small damage on the structure, structural rigidity is almost the } \\
\text { same as before the earthquake }\end{array}$ \\
\hline LS & $\bigcirc$ & $\begin{array}{l}\text { Damage from small to medium. Structural rigidity is reduced but } \\
\text { still has a considerable threshold for collapse }\end{array}$ \\
\hline CP & $\bigcirc$ & $\begin{array}{l}\text { Severe damage to the structure, strength and stiffness decreases } \\
\text { a lot }\end{array}$ \\
\hline C & $\bigcirc$ & $\begin{array}{l}\text { The maximum shear force limit can still be retained by the } \\
\text { building }\end{array}$ \\
\hline D & $\bigcirc$ & $\begin{array}{l}\text { Strength degradation of the structure is large, the frame structure } \\
\text { is unstable and almost collapse }\end{array}$ \\
\hline E & & The structure is unable to withstand shear forces and collapse \\
\hline
\end{tabular}

More importantly, during the analysis process will start from the first step to the end and the program will gradually mark spherical points (small circle) as notification of the decrease in the strength of the structure. Referring to the pushover analysis of the KJ-P5 model having the slim column dimension of $300 \times 650 \mathrm{~mm}$, the plastic hinge results of the performance points in the four directions are presented in Fig. 3. The color level showing in Fig. 3 marks the strength degradation after reaching the step-14, whilst Fig. 4 displays the plastic hinges occurring on the 3rd frame in the x-direction. 


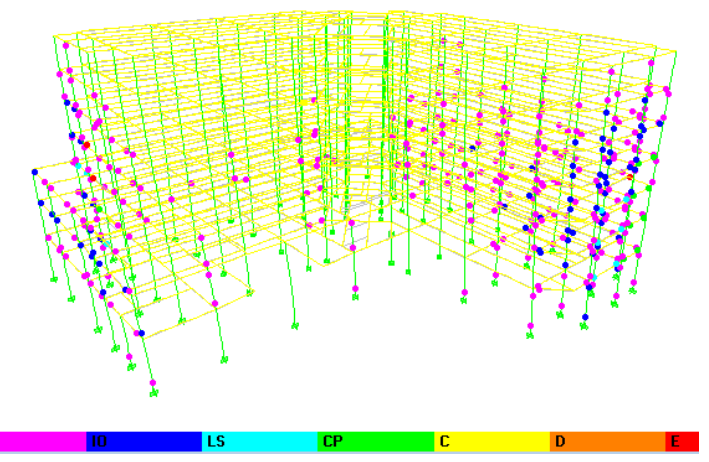

Fig. 3 Plastic hinge location at step-14 of a pushover in the x-direction (N-S) of KJ-P5 model

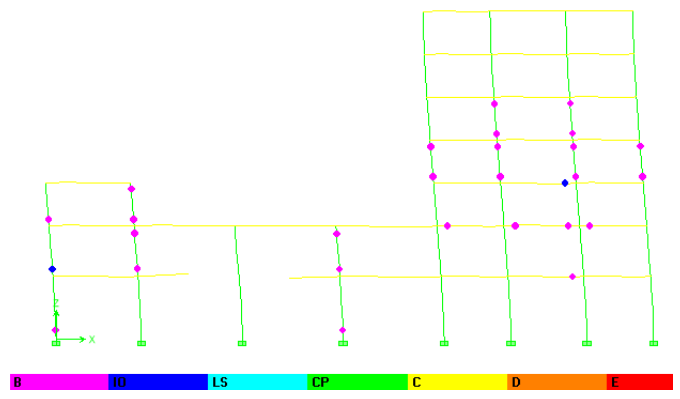

Fig. 4 Plastic hinge location: step-14 of the $3^{\text {rd }}$ frame in X-direction (N-S) of KJ-P5 model

Fig. 3 and Fig. 4 show that the points of damage to the structure elements experienced by columns and beams. In step-14, there are many plastic hinges that occur and have exceeded the limit of immediate occupancy conditions, even there are several points of the beam element being damaged until the final collapse is marked in red. The $3^{\text {rd }}$ frame in the $\mathrm{x}$-direction (north to south) shown in Fig. 4 has experienced the initial plastic hinge marked with purple color and there is 1 point of column structure element and the beam is in immediate occupancy condition.

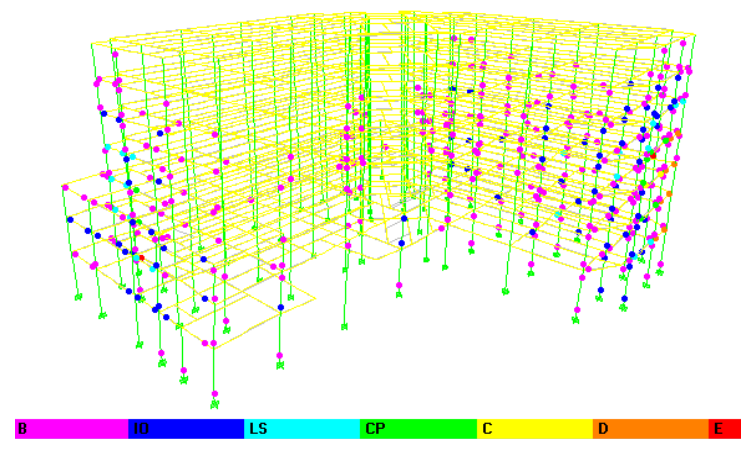

Fig. 5 Plastic hinge location: step-19 of a pushover in X-direction (S-N) of KJ-P5 model 


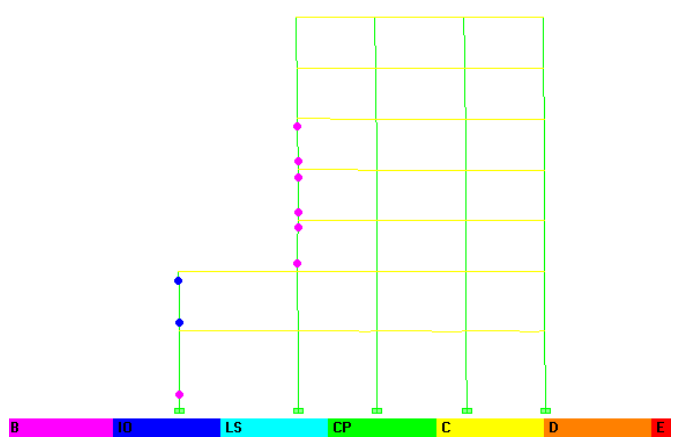

Fig. 6 Plastic hinge location: step-19 of the D frame in X-direction (S-N) of KJ-P5 model

Similarly, the x-direction from the north to the south, in the opposite direction is the south to the north. In the $19^{\text {th }}$ step, it is shown that many plastic hinges that occur are over the immediate occupancy condition, and even there are several points of the beam element being damaged until the final collapse is marked in red (Fig. 5). In Fig. 6 the D frame in the $\mathrm{x}$-direction from the south to the north has experienced an initial plastic hinge marked with purple and there are 2 points of column structure elements already in immediate occupancy conditions.

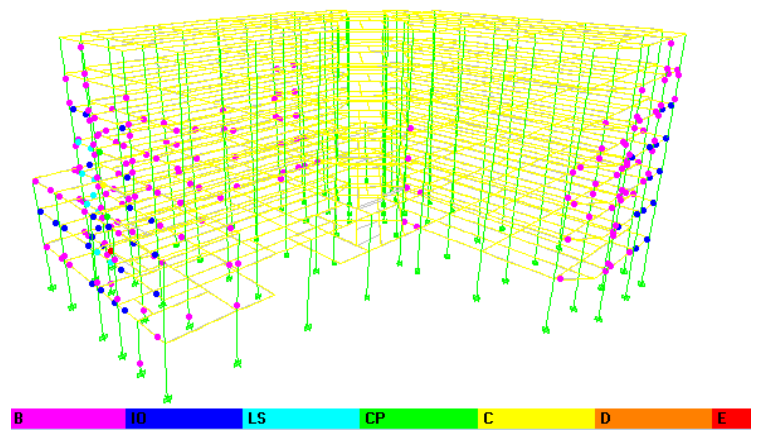

Fig. 7 Plastic hinge location: step-4 of a pushover in Y-direction (W-E) of KJ-P5 model

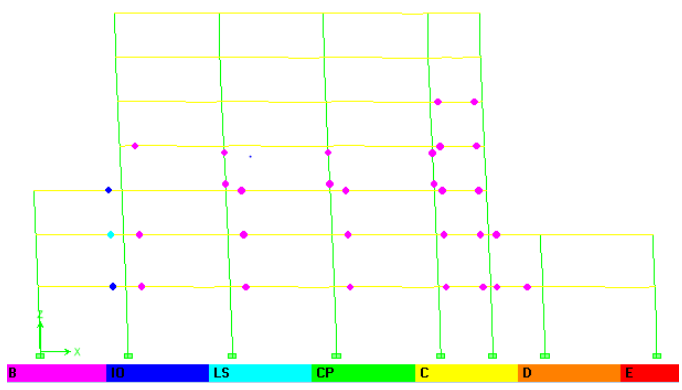

Fig. 8 Plastic hinge location: step-4 of the 7-frame in Y-direction (W-E) of KJ-P5

In the step- 4 denoted in Fig. 7 presents many plastic hinges on the beam and columns that occur already in the condition of immediate occupancy (IO), there are even some points of the beam element damaged in the condition of immediate occupancy. The 7-frame in the y-direction as shown in Fig. 8, many column structural elements undergo initial 
plastic hinges as marked with a purple color and there are 2 beam element points have been already in the immediate occupancy (IO) condition and the column element point in life safety condition (LS).

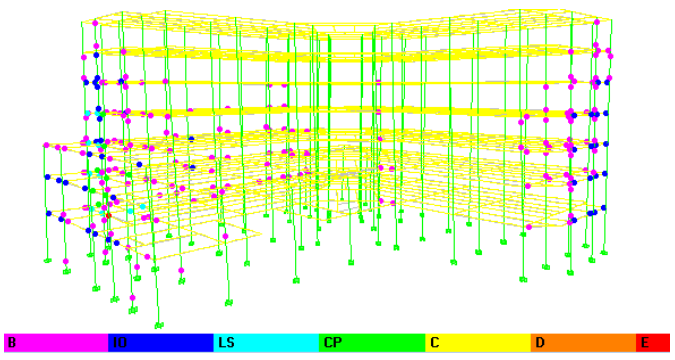

Fig. 9 Plastic hinge location: step-4 of pushover in Y-direction (W-E) of KJ-P5 model

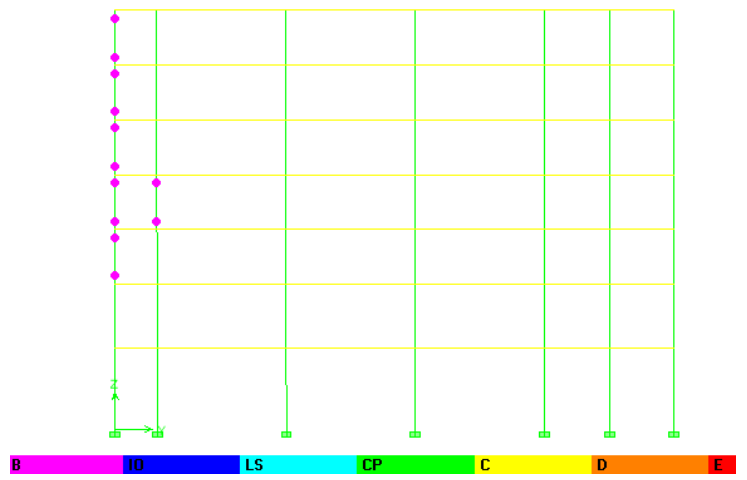

Fig. 10 Plastic hinge location: step-4 of the H-frame in Y-direction (W-E) of KJ-P5 model

Similar to the step- 4 in the y-direction from the west to the east or otherwise as presented in Fig. 9 and Fig. 10, it is resulted many plastic hinges on the beams and columns that have been already in immediate occupancy (IO) conditions, but several points of the beam elements have exceeded the immediate occupancy conditions.

Based on the pushover analysis results, the percentage of damage to the column structure can be determined. In the north to the south of the x-direction, the percentage of damage to the column structure is about $38.39 \%$ of the total damage throughout the structure of the Inna Garuda Hotel. Whilst, for the x-direction of the south to the north, the percentage of column structure element damage is approximately $42.57 \%$. Given this condition, the damage to column structure elements is lesser compared to the beam structure elements. In the west to the east of the y-direction, the column damage percentage is $28.46 \%$ while in the opposite direction the total column structural damage is $26.57 \%$ of the total damage to the structural elements of the Inna Garuda Hotel. For the sake of damage comparison, the performance level of the slim column structural elements is advantageously presented in the following figures. 


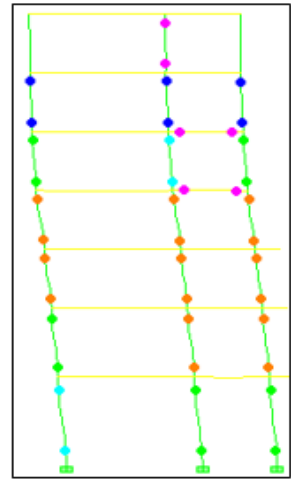

(a) Existing

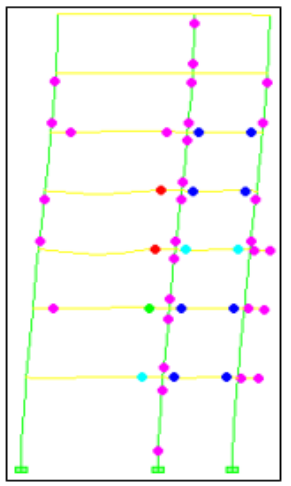

(b) KJ-P5

Fig. 11 Plastic hinge location of slim columns: final step of the A-frame in X-direction (N-S)

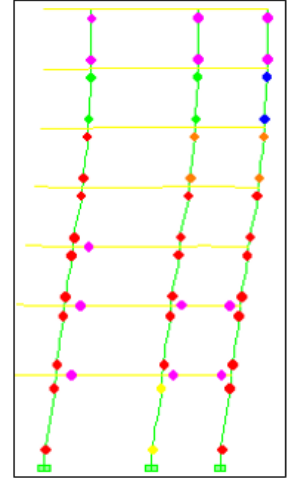

(a) Existing

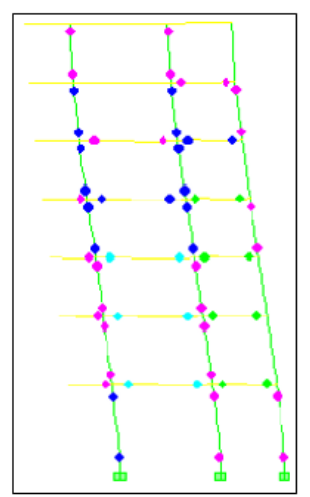

(b) KJ-P5

Fig. 12 Plastic hinge location of slim columns: final step of the O-frame in X-direction (N-S)

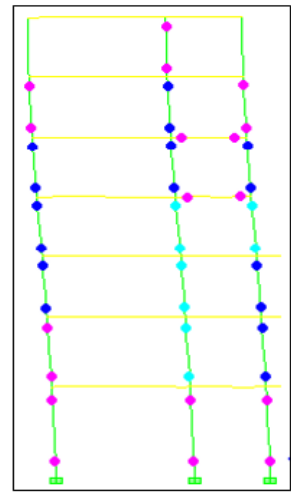

(a) Existing

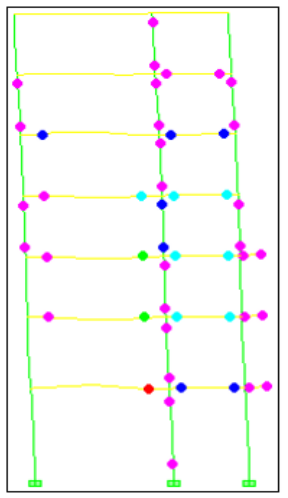

(b) KJ-P5

Fig. 13 Plastic hinge location of slim columns: final step of the A-frame in X-direction (S-N) 


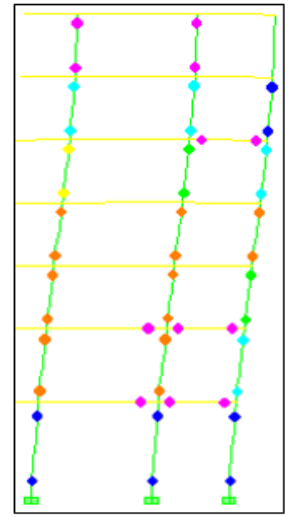

(a) Existing

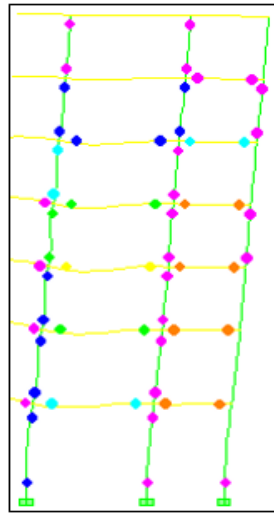

(b) KJ-P5

Fig. 14 Plastic hinge location of slim columns: final step of the O-frame in X-direction (S-N)

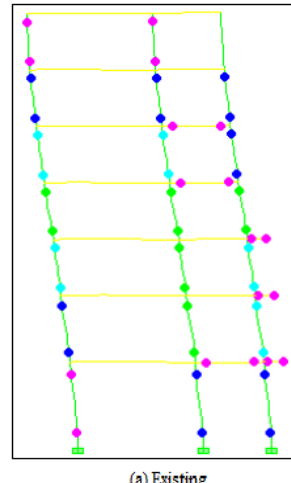

(a) Existing

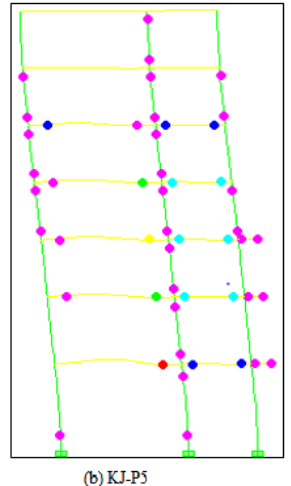

(b) KJ-P5

Fig. 15 Plastic hinge location of slim columns: final step of the A-frame in X-direction (W-E)

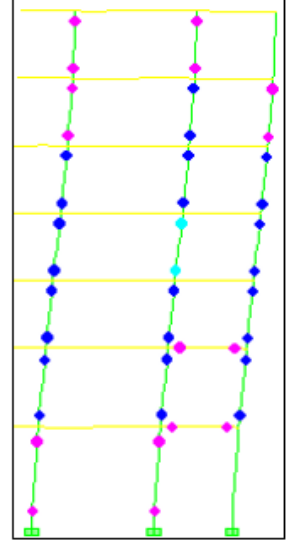

(a) Existing

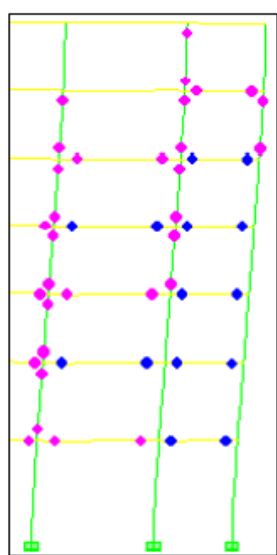

(b) KJ-P5

Fig. 16 Plastic hinge location of slim columns: final step of the O-frame in X-direction (W-E) 
Fig. 11 to Fig. 18 show that by strengthening the cross-section of indicated weakcolumn elements (slender columns) changing the level of damage and improve the performance level of the extended building of Inna Garuda Hotel. The result of pushover analysis of the building structure proves that the reinforced column elements that have been strengthened contribute significantly to the improvement of overall structural performance.

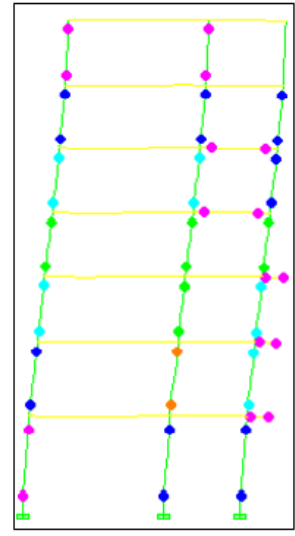

(a) Existing

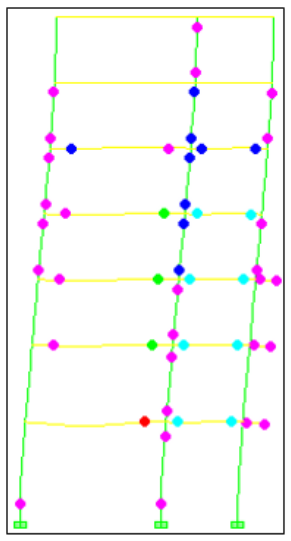

(b) KJ-P5

Fig. 17 Plastic hinge location of slim columns: final step of the A-frame in Y-direction (E-W)

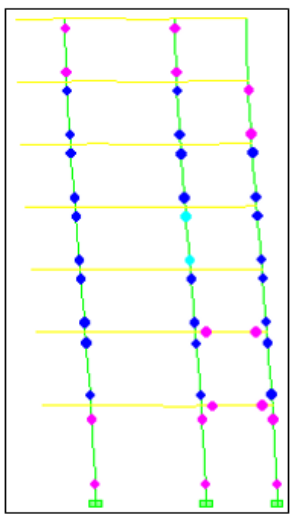

(a) Existing

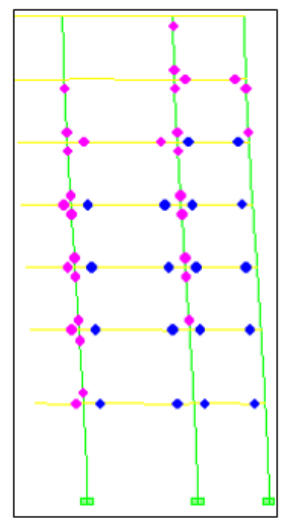

(b) KJ-P5

Fig. 18 Plastic hinge location of slim columns: final step of the O-frame in Y-direction (E-W)

\section{Concluding Remarks}

Based on the recent pushover analysis of the existing building structure by utilizing a strengthening technique of the reinforced concrete jacketing on the slim columns which are indicated to be weak in withstanding earthquake loads, it can be concluded that some pointers as follows.

a. In the pushover analysis in the 4 directions of the lateral force on the KJ-P5 model has obtained a drift ratio value of less than $1.0 \%$ in a slender magnified column with KJ-P5 simulation model with dimensions of $300 \times 650 \mathrm{~mm}$. In this simulation, the performance level of immediate occupancy (IO) is fulfilled. With the performance level 
of immediate occupancy, the building does not show any significant damage to structural components, both strength and stiffness are almost identical to the conditions before the earthquake and remains functional.

b. The plastic hinges propagate the damage locations to the structural elements. The $\mathrm{x}$ direction from the north to the south, total damage of structural elements of the column is $38.39 \%$ from the total damage of the existing structure, while in the opposite direction that is equal to $42.57 \%$ from total damage that exists in the x-direction from the south to north. For the y-direction from to the west to the east, the total damage occurring to the column structure element is $28.46 \%$, while another direction, the total damage occurs at the column structure element of $26.57 \%$ of the total overall damage.

\section{References}

1. Moehle, P. Jack. Seismic design of reinforced concrete special moment frames: a guide for practicing engineers, National Institute of Standards and Technology (NIST), US Department of Commerce, California (2008).

2. Satyarno, I. Some Practical Aspects in the Post Yogyakarta Earthquake Reconstruction of Brick Masonry Houses, the Yogyakarta Earthquake of May 27, 2006, Star Publisher, USA (2007).

3. FEMA 302. NEHRP Recommended Provisions for Seismic Regulations for Buildings and Other Structures, Building Seismic Safety Council, Washington, DC (1997.

4. Patria, Rizaldi. Performance Evaluation Building Structure Building Case Study at Inna Garuda hotel Extension Yogyakarta, Master of Civil Engineering, Islamic University of Indonesia, Yogyakarta (2017).

5. Novia, Mahlisani. Pushover Analysis of Existing Building Structures With Concrete Jacketing Simulation in Some Structural Column Elements, Master of Civil Engineering, Islamic University of Indonesia, Yogyakarta (2017)

6. SNI 03-1726-2012. Earthquake Resilience Planning Standard for Building Structure and Non-Building. National Standardization Body of BSN, Jakarta (2012).

7. ATC-40. Seismic Evaluation and Retrofit of Concrete Buildings, Vol 1, Applied Technology Council, Redwood City, California, USA (1996).

8. Widodo. Seismology and seismic techniques, Department of Civil Engineering, Islamic University of Indonesia, Yogyakarta (2007).

9. Satyarno, I., Nawangalam, P. SAP 2000 Short Course Module, Computing Laboratory, Civil Engineering Department, Faculty of Engineering, Gadjah Mada University, Yogyakarta (2009).

10. Dewobroto, W. Performance Evaluation of Earthquake-Resistant Steel Structures with Pushover Analysis, Pelita Harapan University, Civil Engineering Journal, Jakarta (2005).

11. Triwoyono, A. Concrete Quality Evaluation and Strength of Building Structure Standing Post-Fire, Traditional Technique and Innovation Technique Paper, Indonesia Construction Experts Association, Jakarta (2005).

12. Murty, CVR, Brzev. Svetlana, Faison, Heidi, Comartin, Craigh, Irfanoglu, Ayhan. Building Behavior Structure Concrete Frame Reinforced Wall Filler of Brick against Earthquake Style, World Housing Encyclopedia, Earthquake Engineering Research Institute and International Association for Earthquake Engineering, Oakland, California (2009).

13. M. Teguh. Structural Behaviour of Precast Reinforced Concrete Frames on a NonEngineered Building Subjected to Lateral Loads. International Journal of Engineering and Technology Innovation, vol. 6, no. 2, 2016, pp. 152 - 164 (2016). 